\title{
Presentación: hacia una Estética Técnico Política
}

\author{
José Pablo Concha Lagos \\ Instituto de Estética, Pontificia Universidad Católica de Chile
}

El amplio campo de lo simbólico occidental ha experimentado, durante poco más de cien años, una irrupción que no solo lo modificó, sino que se constituyó en el propio fundamento de la experiencia del sujeto. Si bien lo técnico en su dimensión industrial ha sido pensado tanto desde la filosofía como desde la antropología, la ciencia y otras disciplinas, ha sido la primera aquella que lo sitúa como «cimiento». Esta caracterización la aleja de la consideración general de mediación y la dispone como un fin en sí mismo. La técnica sostendría la experiencia, incluso dándole su sentido, pero no solo como una base estructural, sino que ella misma modelaría aquello que es posible de experimentar. Así, la técnica define los límites de la «realidad», lo que obliga a pensar precisamente la relación compleja entre técnica y poder en tanto administración y dominio de esta realidad, siendo esta la que impone el modo técnico.

El alcance de lo técnico se filtra hacia dispositivos que tienen por finalidad simbolizar al mundo. De esta manera, se transforma en objeto privilegiado para ser pensado desde la estética. Si argumentamos a favor de la importancia de lo técnico en el acontecer cotidiano, vemos que estos dispositivos son extensiones y mediaciones del propio cuerpo respecto del mundo, constituyéndose en configuradores del modo de percibir y de lo percibido. Por esta razón, si la experiencia es mayoritariamente técnica, es mayoritariamente estética. Este despliegue encontró, ya en el siglo XIX un lugar especialmente favorable: la producción artística.

La técnica artesanal de producción artística experimenta una superación radical con la aparición de la fotografía. A pesar de incomprensiones y resistencias, termina por imponerse en circuitos de validación simbólica. Distinto lo ocurrido con el sonido; el registro sonoro será, en primer lugar, la reproducción de la voz humana y luego el sonido de la música, pero será hasta entrado el siglo xx , en que el propio registro sonoro se constituiría, en sí mismo, en obra de arte. El tránsito va de lo artesanal a lo industrial en la propia creación artística, es decir, con la reproductibilidad técnica se incorpora la lógica industrial de producción de arte.

«El extenso campo de lo técnico» se transforma en el amplio reino de lo estético. Ya no solo como producto artístico, sino como objeto que en su mero soporte resignifica la experiencia, privilegiando, en sentido amplio, lo técnico. Por esto, la contemporaneidad es fundamentalmente estética. La tecnología es el terreno del intercambio económico y simbólico; las estrategias de comercialización transforman los objetos comercializables en objetos estéticos al incorporar, para su manejo, la visión 
y la audición, siendo estos los sentidos favorecidos en la tradición estética occidental, al que se suma el tacto como nuevo sentido. Los objetos contienen imágenes y sonidos que interactúan con el sujeto, definiendo lo simbólico como estructurante de lo económico y del ambiente natural de los individuos. Los aparatos técnicos, que han tenido su origen como herramientas auxiliares de la experiencia, se transformaron en dispositivos simbolizadores productores de arte.

Lo comprometido, a partir de la «súper estructura económico-simbólica», en la relación estética y técnica se proyecta en y comprende distintos niveles de despliegue de los sujetos, que van desde relaciones sociales colectivas, hasta el ámbito de lo cotidiano. Esta expansión tendrá consecuencias políticas en tanto sistema ordenador de las relaciones sociales; en otras palabras, las decisiones respecto de las tecnologías siempre serán ideológicas, porque determinan o borran las coordenadas de extensión temporal y espacial en las que acontece el individuo. La pregunta que surge inevitablemente es: ¿qué tipo de sujeto es aquel que es el resultado de aplicaciones tecnológicas impuestas por las culturas hegemónicas? En esta pregunta aparece la antigua querella de la «identidad latinoamericana», asunto que ha ocupado buena parte de la teoría regional.

La relación entre «lo latinoamericano» y la técnica es una de naturaleza confrontacional, en la medida en que «lo latinoamericano» se ve invadido y dependiente de la técnica como estructuradora de «realidad». La «realidad» tiene hoy este carácter, resultado de determinaciones ideológicas hegemónico-económicas de las industrias globales. Este panorama de aspecto dramático es, en lo cotidiano, sutil y lleva a creer que es banal preguntarse por esta relación.

A su vez, respecto del sujeto, el reconocimiento de sus características particulares confronta referencias conceptuales que lo definen refractariamente con sistemas ideológico-conceptuales que le imponen una pertenencia y posicionamiento en los «bordes» del territorio hegemónico.

Estimamos que la teoría latinoamericana ha sido considerablemente más fértil en la reflexión sobre el «sujeto» que la propia filosofía latinoamericana, siendo esta una disciplina tensionada por la dependencia epistemológica del discurso hegemónico y por la necesidad de una originalidad conceptual regional. Si bien la globalización debilitaría los límites territoriales políticos cuando de estructuras conceptuales interpretativas del sentido se trata, más se arraiga el concepto de «identidad» como uno de carácter trascendente regional. La tensión entre imposiciones industriales de sentido debe enfrentarse desde un sustrato conceptual regional y precisamente la tecnología nos obliga a pensar las neocolonizaciones.

Una primera cuestión es que, como ya se ha dicho en muchos lugares, la red elimina las coordenadas tradicionales de tiempo y espacio. El tiempo se transforma en uno de carácter mítico. Es como si el éxtasis tecnológico nos condujera a un éxtasis místico. El eterno retorno de lo mismo se transforma en la forma y en el contenido; estructura y sentido como una sola unidad de significación. La garantía de disponibilidad de información indiscriminada ofrecería una pretendida 
democracia simbólica accesible o, de lo contrario, deseada para el desarrollo de las naciones. Pero esta accesibilidad tiene como contraparte la indefinición del receptor, más aún, ya no es necesario. Infinidad de sitios, o plataformas se construyen sin siquiera esperar que sean vistos. El sujeto puede establecer dos modalidades de relación con la red. La de mero operario o de receptor, es decir, aquel que la utiliza como medio para acceder a información; o, a partir de la llamada web 2.0, ya no es mero operario sino que además programador y de este modo ya no es operario de una herramienta, sino que es un «diseñador» de una herramienta posible en la red. Lorenzo Vilches afirma que «La red no es parte de ningún metarrelato. La imagen toma el lugar de la Historia». Este aserto puede ser interpretado a partir de la hiperdisponibilidad, lo que implica la anulación de la temporalidad lineal, ya que en la imagen todos sus elementos se dan a la vez. Es cierto que su lectura implica una temporalidad de pasar de un lugar a otro, la diferencia es que en la red toda la información sería desjerarquizada. Si bien esto último es en realidad una fantasía, debido a privilegios de determinados motores de búsqueda y sus regionalizaciones de la información, sí es relevante pensar que no hay historia en la medida que toda la información está sobre una misma superficie técnica. La información se atomiza, se desprende de sus contextos de aparición, el conocimiento se transforma en dato porque, como diría Benjamin, los arranca de la tradición. La red sería la consumación extrema de la pérdida aurática.

Si la red es para la contemporaneidad la plataforma de simbolización imaginaria, es entonces la proyección de su modo de despliegue, de su habitabilidad. La corporalidad cede su lugar a las representaciones.

Esta descripción inevitablemente puede tener dos lecturas: por un lado, quienes ven amenazada la naturaleza tradicional de la experiencia; por otro, quienes verían una apertura de posibilidades por la disposición técnica del mundo. En uno u otro caso un elemento sustancial que se pone en juego es la naturaleza del individuo.

La caracterización del hombre actual, como sujeto técnico, parecería no provocar mayor dificultad; a lo largo y ancho del mundo todo individuo depende de herramientas de carácter técnico para operar y para subsistir. Lo crítico de esta imagen es el alcance en sociedades receptoras de lo técnico, como la latinoamericana, en la medida que la configuración de las coordenadas de la existencia y de lo existente son determinadas técnicamente por ideologías foráneas.

Si las herramientas son aquellas que se nos proveen, sólo podremos construir los objetos que esas herramientas permiten; y esta decisión estará más allá de nuestra voluntad. Si pensamos que es cultura todo aquello que no es natural, es decir, todo aquello «construido» por nosotros mismos, vemos que nuestra cultura está constreñida a las posibilidades que otros imponen. Nuestra libertad espiritual fue decidida por las transnacionales productoras de TICs (tecnologías de la información y comunicación), es como si nosotros fuéramos un tic de las economías hegemónicas, una anomalía útil en tanto consumidora. 
Estas tecnologías se constituyen en redes sobre la base de las imágenes; y las que no lo hacen por medio de ellas, lo hacen a través del lenguaje escrito, pero, nuevamente, a partir de una limitación de caracteres. Es decir, la preminencia de la imagen es innegable. Sabemos que no hay momento histórico en que se hayan producido más imágenes, pero una constatación alarmante es que para que una imagen sea verdaderamente eficiente el objeto referencial debe estar ausente; es decir, los TIC promueven la soledad sobre la superficie imaginante de las imágenes y de la macilenta literalidad de los escasos caracteres.

Habitamos en la imagen, pero esto no nos convierte en «imaginarios», diría que, al contrario, en el paroxismo de la imagen somos especialmente analfabetos, esto no es novedad, pero sí nos vuelve vulnerables a las neocolonizaciones imaginarias. Esta descripción no nos resulta desconocida, y somos testigos de una pulsión digital que ve como conveniente la digitalización del sistema escolar, como un paso para estrechar la brecha tecnológica, asunto que es contradicho por cifras que indican que el uso del computador en las salas se restringe a la mera comunicación y búsqueda de información, pero en ningún caso como herramienta pedagógica y menos creativa. En este sentido, el receptor tecnológico de internet sigue siendo un sujeto pasivo; la ilusión de la web 2.0 como espacio interactivo es aún muy limitada.

Si decimos que la red es la persistente revolución tecnológica y depositaria de «todos los contenidos simbólicos posibles», el desafío estético consiste en descifrar el programa simbólico que determina estructuras y flujos de sentido, ya no es la obra quieta y silenciosa sobre el muro, ni la imagen proyectada, ni el texto impreso. Dicho programa es evidentemente uno de carácter geopolítico-económico, así la estética se transforma en una disciplina especialmente preparada para abrir el mundo que se cierra en el facilismo técnico. Si la técnica es el nuevo espacio de sentido, la estética la interpela desde la interpretación que hace del sujeto que de ella depende y de este modo se expande el horizonte simbólico de su habitabilidad. La estética se levanta como la disciplina filosófica privilegiada debido a que es el contexto técnico el que determina esta habitabilidad y su sentido. Si somos menos radicales y decimos que la técnica no es el fundamento, lo que es innegable es que la libertad se circunscribe a las posibilidades que los dispositivos entregan, de este modo, la estética es la filosofía propicia que tiene como imperativo ético pensar al ser humano. Esta radical proposición nos permite alterar el principio sartreano de que «la existencia precede a la esencia»y hoy diríamos que «la técnica precede a la existencia» y esto no es mera retórica, es el propio ser humano que se construye y se modifica, tal vez el riesgo es pensar que hoy el hombre se transforma en su propio fin. Si bien nuestro territorio latinoamericano no define ni produce las tecnologías, al menos deberá transformarse en la resistencia simbólica y resituarla dentro que las coordenadas que la propia experiencia latinoamericana defina. De este modo, la estética se transforma en filosofía política.

Este dossier cubre estos y otros problemas a partir del análisis de materiales específicos. Esta es la peculiaridad filosófica de la estética, es una fenomenología 
aplicada a objetos culturales que se ofrecen estéticos. Se presentan trabajos que consideran definiciones de lo técnico desde una perspectiva arcaico-artesanal, como es el caso de las flautas precolombinas. En este mismo ámbito musical, ahora desde tecnologías contemporáneas, se reflexiona a partir de la composición algorítmica, que son interpretadas a partir de modelos técnicos actuales. La imagen fotográfica, en su versión material (haluros de plata), como en su versión «lingüística» (digital, numérico binaria), son parte central de este dossier; por un lado, se reflexiona desde la creación fotográfica; como por otro, desde los asuntos que involucra el nuevo lenguaje material de esta imagen como sistema de representación y a partir de esto las implicancias políticas de su manejo. Este asunto (lo político), se reflexiona de manera especialmente fértil en la relación compleja entre los dispositivos tecnológicos y el cuerpo en lo que se denomina la estética bio-política. De esta manera, Aisthesis instala la necesaria reflexión respecto de la compleja relación contemporánea entre estética y técnica. 